\title{
The Long and Arduous Journey to Truth-in- Sentencing in Wisconsin
}

Thomas J. Hammer

Marquette University Law School, thomas.hammer@marquette.edu

Follow this and additional works at: http://scholarship.law.marquette.edu/facpub

Part of the Law Commons

Publication Information

Published as Thomas J. Hammer, The Long and Arduous Journey to Truth-in-Sentencing in

Wisconsin, 15 Fed. Sent'g Rep. 15 (2002). (C) 2002 by the Regents of the University of California on behalf of the Vera Institute of Justice. Copying and permissions notice: Authorization to copy this content beyond fair use (as specified in Sections 107 and 108 of the U. S. Copyright Law) for internal or personal use, or the internal or personal use of specific clients, is granted by the Regents of the University of California on behalf of the Vera Institute of Justice for libraries and other users, provided that they are registered with and pay the specified fee via Rightslink ${ }^{\circledast}$ on Caliber (http://caliber.ucpress.net/) or directly with the Copyright Clearance Center, http://www.copyright.com.

\section{Repository Citation}

Hammer, Thomas J., "The Long and Arduous Journey to Truth-in-Sentencing in Wisconsin" (2002). Faculty Publications. Paper 136. http://scholarship.law.marquette.edu/facpub/136

This Article is brought to you for free and open access by the Faculty Scholarship at Marquette Law Scholarly Commons. It has been accepted for inclusion in Faculty Publications by an authorized administrator of Marquette Law Scholarly Commons. For more information, please contact 


\section{The Long and Arduous Journey to Truth-in-Sentencing in Wisconsin}

In 2003 , Wisconsin will complete a transition from indeterminate sentencing to its own rendition of truthin-sentencing. That transition began with legislation passed in I998. In the interim, the story has been one of piecemeal implementation vexed by a gridlocked state legislature.

This Article traces the Wisconsin journey to truth-insentencing. Along the way, it describes the indeterminate system that was abandoned, the early foundations for a new system, the vital supplemental legislation that was needed to make the new system work as originally intended, and the incredible difficulty of getting that legislation passed. Also recounted is the saga of how a statute that was not really intended to take effect without supplementation did just that.

\section{Life in the Old Indeterminate World}

Prior to December 3I, I999, Wisconsin utilized a conventional indeterminate sentencing system. The legislature had established maximum penalties for each offense; for most crimes, probation was also an option. Some minimum penalties were specified, but many of these were presumptive only. In most instances, if the court imposed a prison sentence for a felony, the inmate became eligible for parole after serving one-fourth of the sentence and was required to be released on parole after completing two-thirds of the sentence.

This indeterminate sentencing system was used in the enforcement of an aging and bloated set of criminal laws. The Wisconsin Criminal Code, in which traditional crimes against persons, property, government, and public order are codified, was last revised as a

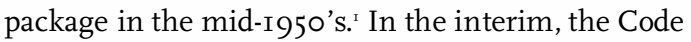
grew dramatically on an ad hoc basis as the state legislature endeavored to respond both to "new bad things" and new ways of doing "old bad things." Similar observations could be made about the host of other crimes scattered throughout the Wisconsin Statutes in specialized chapters dealing with controlled substances, motor vehicles, natural resources and other diverse subjects. Wisconsin lawmakers also participated vigorously in the national phenomenon of enacting countless penalty enhancement statutes.

Against this backdrop, the legislature chose in June I99 8 to join the growing list of jurisdictions that had abandoned the indeterminate model of sentencing. It replaced that model with a truth-in-sentencing system through the passage of a session law known commonly in Wisconsin as "Act 283."

\section{Act 283: The Infrastructure for Truth-in-Sentencing in Wisconsin}

Act 283 worked a sea change in Wisconsin sentencing policy as it affects felons sentenced to the state prisons. For felonies committed on or after December 3I, I999, the judge must split the sentence into two component parts: a term of confinement in prison followed by a term of extended supervision in the community. ${ }^{4}$ The "truth" in Act 283 sentences is that the defendant must serve the entire confinement term as ordered by the court at the time of sentencing before being released to community supervision. There is no provision for early release from prison upon serving a designated percentage of the confinement term. ${ }^{5}$ There are special rules for determining whether a person convicted of a life imprisonment felony may ever apply for release to community supervision.

The policy underlying the enactment of Act 283 is evident. The Wisconsin legislature wanted a system in which there is absolute certainty regarding the length and service of prison sentences. The concept is that, at the time sentence is imposed, the court, the lawyers, the defendant, the victim, and anyone else who is interested in the case will know exactly how long the offender will be in prison. Gone were the days in which an indeterminate term of years would be imposed but it was anyone's guess how long the defendant would be in prison before the parole commission, operating within the parameters described above, ordered release.

Act 283 may be fairly characterized as establishing the infrastructure for truth-in-sentencing in Wisconsin. ${ }^{6}$ Its provisions effectuate the break from the old indeterminate model and create a new bifurcated structure for criminal sentences. Although the Act speaks in some detail about the nature and service of the new type of sentence, it is clear that the legislature did not envision it going into effect without considerable supplementation. This is obvious from language in the bill delaying its effective date from June I998 (the time of passage) to December 1999 and creating a Criminal Penalties Study Committee to develop supplementary legislation on a schedule that would allow for its passage before the new system went into effect.

\section{The Criminal Penalties Study Committee: Creating the Superstructure for Truth-in-Sentencing} The Criminal Penalties Study Committee established by Act 283 was an I8-member bipartisan committee that included judges, prosecutors and defense attorneys,

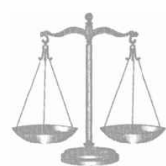

\section{THOMAS J. HAMMER}

Associate Professor of Law, Marquette University Law School.

Professor Hammer served as a member of and the reporter for the Criminal Penalties Study Committee, which was constituted to develop implement ing legislation for truth-in-sentencing in Wisconsin 
legislators, academics, law enforcement and corrections officials, and members of the public. The legislature provided numerous and challenging charges to the committee, including the creation of a uniform classification system for all felonies in the Wisconsin statutes (including those scattered in the far reaches of the statute books) and the classification of each felony and serious misdemeanor in a manner that placed crimes of similar severity into the same category. The legislature also directed the committee to make recommendations for the creation of a sentencing commission to develop advisory sentencing guidelines and to devise some temporary guidelines. Finally, in response to extant problems with revocation of community supervision, the legislature asked the committee to suggest rules for improving the efficiency and efficacy of the revocation process.

On August 3I, I999, after a year of intensive labor, the committee produced its final report for the legislature, including a draft of the supplementary legislation called for in Act $283 .{ }^{7}$ The timing of the report allowed for its proposals to be considered by the legislature before the commencement of truth-in-sentencing on December 3I, I999.

\section{A. A New Felony Classification System}

The committee devised a new classification system for felony offenses. It consists of nine classes of crimes. With the exception of the life imprisonment classification, a maximum initial term of confinement in prison and a maximum term of extended supervision are specified for each of the remaining eight classes. Into that classification system the committee placed close to 500 felony offenses, reserving the higher classes for the most serious crimes against the person and cascading the remainder of crimes against the person, as well as property, drug and other offenses, throughout the middle and lower ends of the spectrum.

To place offenses into the new classification system, the committee used a conversion process that began with a determination of the maximum amount of time that could be served in prison in the old indeterminate system prior to mandatory release on parole if a maximum sentence were imposed. Once this number was identified, the committee used it to locate each crime in the new classification system by searching for a category with a similar maximum initial term of confinement in prison. After this conversion was done, some upward and downward adjustments were made to keep crimes of roughly similar severity in the same category.

This approach to crime classification respected earlier legislative judgments made about the seriousness of offenses and the appropriate maximum penalty for each crime. However, those maximum penalties were enacted in the old indeterminate world. Because there was no evidence in Act 283 that the legislature wanted longer terms of incarceration after truth-insentencing went into effect, the committee needed to translate those old indeterminate penalties into their functional equivalent in the truth-in-sentencing world. The conversion process described above accomplished this by taking into account mandatory release dates in the old indeterminate world.

\section{B. Elimination of Most Minimum Penalties and Penalty Enhancers}

For most crimes, Wisconsin has traditionally given the court the discretion to impose probation as a disposition. Minimum prison penalties existed, but were typically presumptive in nature. The committee recommended that most of these minimum prison penalties be eliminated. It attempted to construct a system of penalty ranges for each crime that would provide the court with an adequate maximum to deal with the worst-case scenario and with a probation option for cases at the other end of the spectrum.

Penalty enhancement statutes cluttered Wisconsin's criminal laws at the time Act 283 was passed. As part of the crime classification process, the committee concluded that its new maximum penalties for each crime provided the court with sufficient leeway to deal with crimes committed in some form of aggravated way. Accordingly, the committee recommended that most of a long list of penalty enhancement statutes be repealed and that the kinds of factual circumstances with which they dealt be codified as "sentence aggravators." A sentence aggravator does not elevate the maximum penalty for the underlying crime, but may influence the judge to sentence more harshly within that maximum range. A few enhancement statutes were retained, for example, the repeat offender law, the weapons enhancer, and the enhancer for certain drug offenses committed near schools and parks.

\section{Temporary Sentencing Guidelines}

Act 283 envisions a process of sentencing in which judges are assisted by advis ory sentencing guidelines. The legislature directed the committee to develop some temporary guidelines for use by the courts until a new sentencing commission is formed and has an opportunity to develop advisory guidelines of its own.

Formulating temporary guidelines was the most contentious aspect of the committee's work. After considering the strengths and weaknesses of the Federal Sentencing Guidelines, as well as those of several other states, the committee opted to devise a guideline system of its own. Ultimately it produced temporary guidelines for eleven offenses that cover the heartland of felony crimes committed in the state of Wisconsin.

For each of the eleven felonies, the guidelines provide a worksheet with a nine-cell graph that charac- 
terizes offense severity on the vertical axis as being "aggravated, intermediate, or mitigated" and offender risk on the horizontal axis as "high, medium, or lesser." By answering a series of questions on the worksheet the judge is guided to a particular cell on the graph as the starting point for identifying an appropriate range within which to sentence the defendant. Accommodations are made for departing upward or downward from that starting point. The committee also produced substantial commentary to accompany the eleven worksheets in order to assist the judge in the evaluation of offense severity and offender risk.

\section{A New Sentencing Commission}

The committee recommended the formation of a permanent sentencing commission and developed a series of tasks for this body. In addition to promulgating sentencing guidelines, the commission would be responsible for such other important functions as collecting, analyzing, and disseminating data about sentencing and its costs (both financial and otherwise). This recommendation responded to the surprising lack of information currently available about sentencing practices throughout the state.

\section{E. Extended Supervision and Its Revocation}

Finally, the committee made a series of recommendations relating to extended supervision, which is that portion of a truth-in-sentencing sentence that is served after release from prison. The committee designed a program of strict supervision aimed at maximizing public safety and allowing offenders to earn their way to greater levels of freedom. It built in a system of sanctioning that would offer alternatives to revocation in appropriate cases. Lastly, the committee developed procedures for greater efficiencies in the process of revoking the supervision of those who fail in that status.

\section{Supplemental Legislation Faces Gridlock in the Legislature}

When the Criminal Penalties Study Committee delivered its report in August I999, there was widespread anticipation that the supplemental legislation it proposed would be enacted in time for the official implementation of truth-in-sentencing on December 3I, I999. That did not happen. Though promptly considered and passed by the state Assembly (with but a few changes), the bill stalled in the Senate. December 3I, I999, came and went; Act 283 went into effect; and the vital supplementary legislation needed to effectuate the original intent of the legislature became trapped in legislative gridlock.

Over the course of the next two and one-half years, the Assembly and Senate considered and passed various bills that for the most part tracked the committee's recommendations. However, differences between bills approved by the two chambers could not be reconciled. Finally, as part of emergency legislation passed in response to a looming billion-dollar state budget deficit, both houses agreed upon a bill that included virtually all of the committee's proposals. It was signed into law by the governor in July, 2002 and will be fully implemented in early 2003. ${ }^{8}$ The critical compromise that made this possible is described in the last section of this article.

While all of these political machinations were transpiring, the sentencing of literally thousands of convicted felons under Act 283 proceeded. Of course, without the supplementary legislation called for by the Act, there was no revision of penalties for their crimes to reflect the great difference between truth-in-sentencing sentences and their indeterminate ancestors. There were no guidelines to help the courts adjust to truth-insentencing. There was no organized dissemination of data to inform judges about the sentencing practices of their colleagues on the bench, either locally or elsewhere in the state. Regardless of one's preference among sentencing systems, it is difficult to imagine a more dreadful way to transition from one to another.

\section{A Compromise to the Rescue: A Little Less "Truth" in Truth-in-Sentencing}

The biggest hurdle to enactment of the supplementary legislation described earlier was the position of some legislators that the Ioo\% style of "truth" in Wisconsin's truth-in-sentencing laws needed modification to allow inmates to petition for early release from prison at some point during their confinement terms. Identifying that point became a critical negotiating issue. Ultimately, a compromise was forged that made passage of the supplementary legislation possible in 2002 .

The compromise removes some of the "truth" from the original truth-in-sentencing law. In short, the new law permits an inmate who has served $85 \%$ of the confinement term for a mid-range felony, or $75 \%$ of the confinement term for a lower-end felony, to petition the court for a sentence adjustment to allow for early release from prison to extended supervision status. Grounds for the motion include the inmate's efforts at, and progress in, rehabilitation. Sentence adjustment is not permitted for the most serious classes of felonies.

Critics have decried the compromise as creating a "glaring loophole" in truth-in-sentencing. Some have said that it will "open the gates" at the state prisons. Others posit that it will turn the courts into "mini-parole boards." But the reality is that the compromise places very substantial limits on sentence adjustments. Not only did the legislature exempt the most serious felonies from adjustment, but it also awarded the prosecutor a veto over any adjustment. ${ }^{9}$ Further, inmates are limited to filing one adjustment petition per sentence.

At the end of the day, a strong argument can be 
made that the sentence adjustment provision was a reasonable compromise to achieve passage of the massive supplementary legislation that should have been enacted three years ago before the truth-insentencing laws ever took effect. True, it removes a modest amount of "truth" from felony sentences. But it brings Wisconsin more in line with many sister jurisdictions that have traveled the truth-in-sentencing route. More importantly, it allows for many substantial improvements to Wisconsin's truth-in-sentencing laws, like the reclassification of all felony offenses and the implementation of sentencing guidance, to finally go into effect. That seems like a fair price to pay.

\section{Notes}

1 A limited number of mini-recodifications of Wisconsin's criminal laws occurred in the 1970's and 1980's. These included revisions of the laws dealing with homicide, sexual assault, and crimes against children. The legislature also implemented a uniform crime classification system in 1977 into which it plugged Criminal Code offenses. However, the classification system has never been utilized for the scores of crimes (both felonies and misdemeanors) that are located in other chapters of the Wisconsin Statutes.
See 1997 WIs. Laws 283.

3 The split sentence requirement described here does not apply to (1) felons who are placed on probation with a withheld sentence, (2) felons sentenced to serve time in local jails, and (3) misdemeanants.

$4 \quad$ Wis. Stat. $\S 973.01$ (1999-2000). The term of extended supervision in the community must be at least $25 \%$ of the length of the term of confinement in prison. Both the judge and corrections officials have power to set conditions of extended supervision.

5 The only way of shortening the confinement term is through a small "boot camp" program available to a limited number of younger felons sentenced to prison who are determined by the judge at the time of sentencing to be eligible and who are later chosen for the program by corrections officials.

6 A detailed description of other facets of Act 283 may be found in Michael B. Brennan \& Donald V. Latorraca, Truth-inSentencing, Wisconsin LaWyer, May 2000, at 14.

7 See Criminal Penalties Study Committee Final Report (Wisconsin Department of Administration, August 31, 1999). This report is available online at <http://www.doa.state.wi.us/ secy/index.asp $>$.

$8 \quad$ See 2001 WIs. Laws 109.

9 In a few limited situations, most of which involve sexual assault, the victim also has veto power over sentence adjustment. 